IZA DP No. 7440

The Scarring Effects of Unemployment, Low Pay and Skills Under-utilisation in Australia Compared

Kostas Mavromaras

Peter Sloane

Zhang Wei

June 2013 


\title{
The Scarring Effects of Unemployment, Low Pay and Skills Under-utilisation in Australia Compared
}

\author{
Kostas Mavromaras \\ NILS, Flinders University and IZA \\ Peter Sloane \\ NILS, Flinders University, \\ WELMERC, Swansea University and IZA \\ Zhang Wei \\ NILS, Flinders University
}
Discussion Paper No. 7440
June 2013

\author{
IZA \\ P.O. Box 7240 \\ 53072 Bonn \\ Germany \\ Phone: +49-228-3894-0 \\ Fax: +49-228-3894-180 \\ E-mail: iza@iza.org
}

\begin{abstract}
Any opinions expressed here are those of the author(s) and not those of IZA. Research published in this series may include views on policy, but the institute itself takes no institutional policy positions. The IZA research network is committed to the IZA Guiding Principles of Research Integrity.

The Institute for the Study of Labor (IZA) in Bonn is a local and virtual international research center and a place of communication between science, politics and business. IZA is an independent nonprofit organization supported by Deutsche Post Foundation. The center is associated with the University of Bonn and offers a stimulating research environment through its international network, workshops and conferences, data service, project support, research visits and doctoral program. IZA engages in (i) original and internationally competitive research in all fields of labor economics, (ii) development of policy concepts, and (iii) dissemination of research results and concepts to the interested public.
\end{abstract}

IZA Discussion Papers often represent preliminary work and are circulated to encourage discussion. Citation of such a paper should account for its provisional character. A revised version may be available directly from the author. 


\section{ABSTRACT}

\section{The Scarring Effects of Unemployment, Low Pay and Skills Under-utilisation in Australia Compared}

There is a substantial literature on the scarring effects of unemployment on future employment prospects and a smaller one on the scarring effects of low pay, but the possibility that skills mismatch in the form of skills under-utilisation, may also have similar detrimental effects, has not previously been considered. This paper uses the first ten waves of the HILDA survey data to investigate the inter-related dynamics of unemployment, low pay and skills under-utilisation in Australia, focussing on differences by gender and educational pathways. It shows that skills under-utilisation also exhibits scarring effects, in addition to earlier evidence on wage penalties and reduced job satisfaction.

JEL Classification: J24, J31, I21

Keywords: $\quad$ education pathways, state dependence, dynamic estimation, job quality

Corresponding author:

Kostas Mavromaras

National Institute of Labour Studies

Flinders University

GPO Box 2100

Adelaide, South Australia 5001

Australia

E-mail: k.mavromaras@flinders.edu.au 


\section{Introduction}

Although Australia experienced relatively low unemployment levels of around 5\% over most of the last decade, getting unemployed people into work remains a core Australian economic and social policy goal. The old debate about why unemployment can be such a "sticky" labour market state continues, and new debates about what happens to the quality of the jobs obtained by those previously unemployed are emerging. Job quality has proved to be an elusive concept in the economics literature, primarily because of the difficulty of quantifying quality in an objective manner. This paper focuses on two direct measures of job quality, namely on whether the job is a low pay job, and whether the job under-utilises the skills of the worker. Both of these measures can be quantified, low pay by the wage and underutilisation by various skills mismatch measures (typically measured by the difference between the skills and qualifications needed for and utilised on the job, and those possessed by the worker). A policy focus on low pay and its implications has been longstanding and intense, as reflected in minimum wage legislation. Although the policy focus on skills underutilisation as a form of skills mismatch in the workplace has only arisen recently, it is currently at the forefront of the policy agenda of many organisations (see, for example, European Commission 2009 and 2012, CEDEFOP 2010 and 2012, and OECD (Desjardins and Rubenson, 2011), based on the view that skill under-utilisation has the potential to lead to losses in productivity and damage competitiveness. Recent notable extensions to the theory underlying skills mismatch reflect the increased attention focused on issues relating to skills mismatch (Sattinger 2012).

It is a well-established result in the literature that adverse labour market circumstances and outcomes may be persistent in the sense that their presence today makes in itself their presence tomorrow more likely. For example, being unemployed today may increase the 
chances of being unemployed tomorrow. Evidence suggests that such persistence is present over and above all other factors that may influence the probability of being unemployed (Heckman, 1981). Related research suggests that skills under-utilisation can be similarly persistent (Mavromaras et al., 2012a and 2012b) and that this varies by the education level of the mismatched worker. There is further evidence that the persistence of unemployment is inter-related with the past values of low pay, that is, previous low pay and previous unemployment act together in determining the probability of current unemployment (Stewart 2007). The study of the inter-related dynamics of unemployment and low pay by Stewart (2007) has revealed that there is a cumulative negative effect from the two types of past disadvantage (unemployment and low pay) that result in an additional adverse impact on current unemployment. There is no similar evidence about whether the self-persistence of unemployment is inter-related with the past values of skills under-utilisation in determining the probability of current unemployment, and this paper sets out to fill this gap.

This paper focusses on the inter-related dynamics of unemployment, low pay and skills utilisation in Australia, principally because of the availability of high quality longitudinal skills under-utilisation data. In particular, the paper examines the extent to which past low pay or past skills under-utilisation, combined with the experience of past unemployment, may influence future employment prospects. To do this, the paper estimates the likelihood of current unemployment as a result of having been previously unemployed, and also of having been previously in low paid or in skills under-utilising employment. Following past research, which shows gender and education level to be both important regarding the outcomes of unemployment, low pay and skills under-utilisation, we carry out and compare separate current unemployment estimations by gender and by individual education level. 


\section{Background}

This section outlines the previous literature and explains how this paper relates to it. A number of studies have examined the extent of state dependence on employment status. For instance, Heckman (1981) and Hyslop (1999) find significant persistence in employment probabilities among married women in the USA. Similar results of strong state dependence in unemployment have also been found for other countries (Narendranathan and Elias, 1993 and Arulampalam et al., 2000 for the UK; Flaig et al., 1993 and Muhleisen and Zimmermann, 1994 for Germany; Frijters, et al., 2000 for Holland). There is also an extensive literature focusing on the state dependence of low quality employment, most of which defines a low quality job as a low paid job. Stewart and Swaffield (1997) find evidence of persistence in low wage employment. Evidence on the persistence of low pay has also been presented by Gosling et al. (1997), Sloane and Theodossiou (1996 and 1998)and Clark and Kanellopoulos (2013).

There is evidence that skills under-utilisation, manifested by mismatch of skills and/or qualifications, leads to lower wages and job satisfaction (Allen and Van der Velden, 2001; Green and Zhu, 2010; McGuinness and Wooden, 2009; Mavromaras et al., 2010 and Baert, Cockx and Verhaest, 2013). Thus, partitioning the employed population into those with wellutilised skills and those with under-utilised skills, can offer one dimension of what is a "good" and what is a "bad” job. Mavromaras et al. (2012a and 2012b) examine the dynamic properties of skills under-utilisation in the workplace and show that over-skilling can be persistent and that the extent of revealed state dependence differs by educational pathway.

The evidence above suggests that, while the individual dynamics of several such labour market states have been examined in isolation from one another, the inter-related dynamics 
between low paid employment and unemployment have been relatively less examined. Stewart (2007) investigates the extent to which low-paid employment negatively affects future employment prospects in the UK, using random effects dynamic models that control for initial conditions and unobserved heterogeneity. He finds that relative to high-paid jobs, low-paid employment has almost as large an adverse effect as unemployment on future employment prospects. Buddelmeyer et al. (2010) apply a similar analytical framework to study this issue in Australia. They find that the adverse effect of low-paid employment on future employment is only significant for females and it is much weaker than the effect of unemployment on repeat unemployment. As the authors acknowledge it is not immediately obvious why there should be a stronger scarring effect on women than on men and we investigate this using more waves of the same data set and a different definition of those in the labour force. Cappellari and Jenkins (2008) confirm the above observation of Stewart (2007) by using a multivariate probit model that also controls for selection into employment and for panel attrition. They also find that unemployed men have a greater chance of becoming low paid than high-paid men do. This paper follows the analytical framework of Stewart (2007) and Buddelmeyer et al. (2010) and finds that the scarring effects of low pay are significant for both men and women and of similar magnitude, though lower than the scarring effects of unemployment.

The paper extends the literature into the area of inter-related dynamics of unemployment and skills under-utilisation. The intuition behind this investigation is that what we conventionally call skills under-utilisation can be defined as partial skills under-utilisation, and what we conventionally call unemployment can be defined as complete under-utilisation. The paper focusses on the following questions. First, it asks what is the effect of skills under-utilised employment on future employment prospects, relative to well-utilised skills employment. 
Second, it asks what the effect of unemployment on future repeat unemployment is, relative to well-utilised skills employment. For the sake of completeness, a similar set of questions is asked in relation to low pay dynamics. Finally, the paper asks whether the inter-related dynamics of unemployment and under-utilised skills employment differ by gender and education pathway.

Our results suggest that, relative to workers with well-utilised skills, workers with underutilised skills are significantly more likely to be unemployed in the next period, but the likelihood of unemployment in the next period is not as high as for those who are unemployed in the current period (but similar to that of the low paid). The adverse effect of skills under-utilisation and unemployment experience on future employment prospects is significant for both males and females with no discernible gender difference. The adverse effect of skills under-utilisation and unemployment experience is significant for all educational categories. Unemployment dynamics appear to be stronger than skills underutilisation dynamics. The adverse effects of skills under-utilisation and unemployment experience are relatively stronger for those with a higher level of educational qualifications.

\section{Data}

The paper uses the confidentialised unit record file from the first ten waves (2001 to 2010) of the Household, Income and Labour Dynamics in Australia (HILDA) household survey. ${ }^{1}$ The sample is restricted to an unbalanced panel of all working-age individuals (16-64 years for males and 16-59 for females) in the labour force who provide complete information on the variables of interest. The self-employed and full-time students are excluded. The sample size we retain is approximately 6,000 observations (persons) per wave over ten years.

\footnotetext{
${ }^{1}$ See Watson and Wooden (2004) for a detailed description of the HILDA data.
} 
We follow the majority of the literature and use two-thirds of the median gross hourly wage as the threshold to define low-paid employment. More specifically, we calculate the median hourly wage using ‘gross weekly earnings from main job’ divided by 'hours per week usually worked in main job' of all working age employees by wave within our HILDA sample and therefore define a person to be in low-paid employment if his or her hourly wage is less than two-thirds of the median hourly wage and more than zero. The thresholds of low-paid employment for each wave are shown in Table 1.

Table 1: Estimated low-pay thresholds: Gross hourly wages in AU\$

\begin{tabular}{|c|c|c|c|c|c|}
\hline & Wave 1 & Wave 2 & Wave 3 & Wave 4 & Wave 5 \\
\hline \multicolumn{6}{|c|}{ Low-pay threshold } \\
\hline \multirow[t]{2}{*}{ Hourly earnings } & 11.33 & 11.79 & 12.23 & 12.61 & 13.33 \\
\hline & Wave 6 & Wave 7 & Wave 8 & Wave 9 & Wave 10 \\
\hline \multicolumn{6}{|l|}{ Low-pay threshold } \\
\hline Hourly earnings & 13.83 & 14.67 & 15.35 & 16.16 & 16.67 \\
\hline
\end{tabular}

The low-pay threshold increases over time as the wages we use are in nominal money terms.

The distribution of employment and pay status by gender and education level is shown is Table $2 .^{2}$

\footnotetext{
2 The numbers in Table 1 are slightly smaller than those reported by Buddelmeyer et al. (2010). This is because our sample is restricted to working age employees, i.e. 16-64 years for males and 16-59 for females, while Buddelmeyer et al. (2010) focused on all adult workers, aged 21 years or older. The distribution of employment and pay status shown in Table 2 is similar to those reported by Buddelmeyer et al. (2010).
} 
Table 2: Employment and pay status by gender and education level

\begin{tabular}{|c|c|c|c|c|c|c|}
\hline & $\begin{array}{l}\text { University } \\
\text { graduates }\end{array}$ & Diplomas & $\begin{array}{l}\text { Certificates } \\
\text { III/IV }\end{array}$ & $\begin{array}{c}\text { Only } \\
\text { completed } \\
\text { school }\end{array}$ & $\begin{array}{l}\text { Did not } \\
\text { complete } \\
\text { school }\end{array}$ & Total \\
\hline \multicolumn{7}{|l|}{ Males } \\
\hline Unemployed (U) & $2.6 \%$ & $3.9 \%$ & $4.3 \%$ & $6.1 \%$ & $11.5 \%$ & $5.9 \%$ \\
\hline Low-paid employee (LP) & $3.8 \%$ & $6.1 \%$ & $8.5 \%$ & $19.8 \%$ & $17.7 \%$ & $11.2 \%$ \\
\hline High-paid employee (HP) & $93.6 \%$ & $90.0 \%$ & $87.2 \%$ & $74.2 \%$ & $70.9 \%$ & $82.9 \%$ \\
\hline No. of observations & 7,591 & 2,700 & 8,936 & 5,068 & 7,769 & 32,064 \\
\hline \multicolumn{7}{|l|}{$\underline{\text { Females }}$} \\
\hline Unemployed (U) & $2.3 \%$ & $3.2 \%$ & $5.8 \%$ & $6.3 \%$ & $9.5 \%$ & $5.5 \%$ \\
\hline Low-paid employee (LP) & $4.3 \%$ & $9.3 \%$ & $15.9 \%$ & $19.1 \%$ & $18.1 \%$ & $12.8 \%$ \\
\hline High-paid employee (HP) & $93.4 \%$ & $87.5 \%$ & $78.3 \%$ & $74.6 \%$ & $72.3 \%$ & $81.6 \%$ \\
\hline No. of observations & 9,283 & 3,083 & 4,822 & 5,347 & 7,923 & 30,458 \\
\hline \multicolumn{7}{|l|}{$\underline{\text { Total }}$} \\
\hline Unemployed (U) & $2.4 \%$ & $3.5 \%$ & $4.8 \%$ & $6.2 \%$ & $10.5 \%$ & $5.7 \%$ \\
\hline Low-paid employee (LP) & $4.1 \%$ & $7.8 \%$ & $11.1 \%$ & $19.4 \%$ & $17.9 \%$ & $12.0 \%$ \\
\hline High-paid employee (HP) & $93.5 \%$ & $88.7 \%$ & $84.1 \%$ & $74.4 \%$ & $71.6 \%$ & $82.3 \%$ \\
\hline No. of observations & 16,874 & 5,783 & 13,758 & 10,415 & 15,692 & 62,522 \\
\hline
\end{tabular}

Note: The sample is working age individuals in the labour force from HILDA 2001-2010.

The skills under-utilisation measure is derived by using the response scored on a seven point scale to the statement "I use many of my skills and abilities in my current job", with a response of 1 corresponding to strongly disagree, up to 7 corresponding to strongly agree. Individuals selecting 1, 2, 3 or 4 on the 1-7 scale are classified as skills under-utilised and those selecting 5 or higher as skills well-matched. The use of a binary indicator of skills under-utilisation is in line with existing research and follows sensitivity analyses suggesting that our results are not particularly sensitive to the precise cut off point used in this paper. Table 3 reports the distribution of employment and skills under-utilisation status by gender and education level, whilst splitting the sample into three mutually exclusive and collectively exhaustive categories: (i) unemployed; (ii) under-utilised skills (1-4 on the scale); and (iii) well-matched skills (5 to 7 on the scale). 
Table 3 shows that the proportion of unemployed workers declines with higher levels of education, starting from $10.9 \%$ for school non-completers, and dropping to $2.4 \%$ for university graduates. In contrast, the proportion of workers with well-matched skills and high paid employment both increase with education level. Such an association between skills utilisation and education level has been explained in the literature (Mavromaras et al., 2009) by the 'bumping down' principle, which suggests that a lack of demand for high skilled labour leads them to seek lower level jobs, resulting in some lower skilled employees being 'bumped down' into even lower skilled occupations with the level of aggregate displacement increasing as we move down the skills spectrum, but there are several other potential explanations for this empirical regularity (Sattinger, 2012). Additionally, workers at the lowest end of the skills and qualifications distributions may be more likely to have been forced out of employment and not be able to return for a longer period of time.

Table 3: Employment and skills utilisation status by gender and educational attainment

\begin{tabular}{|c|c|c|c|c|c|c|}
\hline & $\begin{array}{l}\text { University } \\
\text { graduates }\end{array}$ & Diplomas & $\begin{array}{c}\text { Certificates } \\
\text { III/IV }\end{array}$ & $\begin{array}{c}\text { Only } \\
\text { completed } \\
\text { school }\end{array}$ & $\begin{array}{l}\text { Did not } \\
\text { complete } \\
\text { school }\end{array}$ & Total \\
\hline \multicolumn{7}{|l|}{ Males } \\
\hline Unemployed (U) & $2.5 \%$ & $3.7 \%$ & $4.3 \%$ & $6.5 \%$ & $12.3 \%$ & $6.0 \%$ \\
\hline Skills under-utilised (OS) & $14.6 \%$ & $18.4 \%$ & $17.5 \%$ & $27.5 \%$ & $25.6 \%$ & $20.3 \%$ \\
\hline Skills well-matched (WM) & $82.9 \%$ & $77.9 \%$ & $78.2 \%$ & $66.0 \%$ & $62.1 \%$ & $73.7 \%$ \\
\hline No. of observations & 7105 & 2478 & 8020 & 4394 & 6730 & 28727 \\
\hline \multicolumn{7}{|l|}{ Females } \\
\hline Unemployed (U) & $2.2 \%$ & $3.1 \%$ & $6.0 \%$ & $6.6 \%$ & $9.6 \%$ & $5.6 \%$ \\
\hline Skills under-utilised (OS) & $14.7 \%$ & $19.7 \%$ & $21.8 \%$ & $26.9 \%$ & $27.9 \%$ & $21.9 \%$ \\
\hline Skills well-matched (WM) & $83.0 \%$ & $77.2 \%$ & $72.2 \%$ & $66.5 \%$ & $62.4 \%$ & $72.6 \%$ \\
\hline No. of observations & 8763 & 2881 & 4390 & 4821 & 7328 & 28183 \\
\hline \multicolumn{7}{|l|}{$\underline{\text { Total }}$} \\
\hline Unemployed (U) & $2.4 \%$ & $3.4 \%$ & $4.9 \%$ & $6.5 \%$ & $10.9 \%$ & $5.8 \%$ \\
\hline Skills under-utilised (OS) & $14.7 \%$ & $19.1 \%$ & $19.0 \%$ & $27.2 \%$ & $26.8 \%$ & $21.1 \%$ \\
\hline Skills well-matched (WM) & $83.0 \%$ & $77.5 \%$ & $76.0 \%$ & $66.3 \%$ & $62.3 \%$ & $73.1 \%$ \\
\hline No. of observations & 15868 & 5359 & 12410 & 9215 & 14058 & 56910 \\
\hline
\end{tabular}

Note: The sample is working age individuals in the labour force from HILDA 2001-2010. 
Table 4 below describes the patterns of labour force status over time by education level. It shows that in spite of significant transitions between employment and pay status as well as between employment and skill utilisation status, these labour force statuses are persistent over time. In general, about $40 \%$ of those unemployed in $t-1$ are still unemployed in $\mathrm{t}, 42.8 \%$ of the low paid remain low paid ,while among those with well-utilised skills in $t-185.7 \%$ continue to be well-utilised in $\mathrm{t}$.

Table 4: Transitions between labour force status by education level

\begin{tabular}{|c|c|c|c|c|c|c|c|}
\hline \multirow[b]{3}{*}{ Status at $\mathrm{t}-1$} & \multicolumn{7}{|c|}{ Status at $\mathrm{t}$} \\
\hline & \multicolumn{3}{|c|}{ Employment and pay } & & \multicolumn{3}{|c|}{ Employment and skills utilisation } \\
\hline & Unemployed & Low-paid & High-paid & & Unemployed & $\begin{array}{l}\text { Skills } \\
\text { under- } \\
\text { utilised }\end{array}$ & $\begin{array}{c}\text { Skills } \\
\text { well- } \\
\text { utilised }\end{array}$ \\
\hline \multicolumn{8}{|c|}{ University graduates } \\
\hline Unemployed & 21.3 & 10.8 & 67.9 & Unemployed & 22.6 & 22.6 & 54.9 \\
\hline Low-paid & 3.4 & 25.3 & 71.2 & Skills under-utilised & 2.4 & 46.4 & 51.2 \\
\hline High-paid & 1.1 & 2.1 & 96.8 & Skills well-matched & 0.9 & 8.2 & 90.8 \\
\hline \multicolumn{8}{|l|}{$\underline{\text { Diplomas }}$} \\
\hline Unemployed & 25.6 & 11.3 & 63.2 & Unemployed & 26.5 & 21.6 & 52.0 \\
\hline Low-paid & 4.3 & 38.4 & 57.3 & Skills under-utilised & 1.8 & 51.8 & 46.4 \\
\hline High-paid & 1.6 & 4.1 & 94.4 & Skills well-matched & 1.4 & 10.8 & 87.8 \\
\hline \multicolumn{8}{|c|}{$\underline{\text { Certificates III/IV }}$} \\
\hline Unemployed & 37.5 & 14.4 & 48.2 & Unemployed & 41.2 & 19.3 & 39.5 \\
\hline Low-paid & 3.7 & 38.3 & 58.0 & Skills under-utilised & 3.1 & 44.6 & 52.4 \\
\hline High-paid & 1.7 & 5.3 & 93.0 & Skills well-matched & 1.6 & 13.1 & 85.3 \\
\hline \multicolumn{8}{|c|}{ Only completed school } \\
\hline Unemployed & 32.9 & 24.8 & 42.3 & Unemployed & 36.7 & 22.8 & 40.5 \\
\hline Low-paid & 3.5 & 47.4 & 49.1 & Skills under-utilised & 3.3 & 52.9 & 43.8 \\
\hline High-paid & 1.9 & 7.5 & 90.6 & Skills well-matched & 1.9 & 16.2 & 81.9 \\
\hline \multicolumn{8}{|c|}{ Did not complete school } \\
\hline Unemployed & 47.2 & 21.1 & 31.7 & Unemployed & 53.2 & 18.8 & 28.0 \\
\hline Low-paid & 6.4 & 48.0 & 45.6 & Skills under-utilised & 3.7 & 53.6 & 42.7 \\
\hline High-paid & 2.4 & 8.4 & 89.2 & Skills well-matched & 2.4 & 18.3 & 79.3 \\
\hline \multicolumn{8}{|l|}{$\underline{\text { Total }}$} \\
\hline Unemployed & 37.8 & 18.5 & 43.7 & Unemployed & 42.0 & 20.3 & 37.7 \\
\hline Low-paid & 4.6 & 42.8 & 52.6 & Skills under-utilised & 3.0 & 50.0 & 47.0 \\
\hline High-paid & 1.7 & 5.1 & 93.2 & Skills well-matched & 1.6 & 12.8 & 85.7 \\
\hline
\end{tabular}


Moreover, we observe that a larger proportion of people move into a higher status position than a lower one. In addition, the probability of being unemployed is almost three times as high for those who were low paid in the previous year relative to the high paid, and correspondingly about twice as high for those who were skills under-utilised compared to those who were well-utilised in the previous year.

The patterns of labour force status over time also vary significantly by education level. The proportion of those remaining unemployed decreases with education level, while the probability of remaining high paid or well matched increases with education level. In addition, the proportion of people moving into a better status position is positively associated with education level.

\section{Methodology}

Following Stewart (2007), the paper uses a random effects dynamic probit model to estimate the likelihood of unemployment. The outcome variable is dichotomous: 1 if unemployed and 0 if employed. We write the latent equation as

$y_{i t}^{*}=\gamma_{1} y_{i t-1}+\gamma_{2} L Q_{i t-1}+X_{i t}^{\prime} \beta+\alpha_{i}+u_{i t}$

where $i=1, \ldots, N$ denotes individuals observed over $t=2, \ldots, T$ periods. $y_{i t}^{*}$ is the latent dependent variable for being unemployed, with the observable outcome $y_{i t}=1$ if $y_{i t}^{*} \geq$ 0 and $y_{i t}=0$ otherwise. $y_{i t-1}$ represents the lagged dependent outcome variable, and $L Q_{i t-1}$ is a dummy variable denoting the lag of low quality employment. Low quality employment is represented by two variables: the first one is being in low paid employment (being paid above the threshold value is the reference category) and the second one is being skills under-utilised (being skills well-matched is the reference category). We estimate the 
impact of the two types of low quality employment on the probability of unemployment separately, where $\gamma_{1}$ and $\gamma_{2}$ are the two coefficients associated with the estimated lags. $X_{i t}$ is a set of control variables which are allowed to be both time-variant and invariant (including age, gender, education level, disability status, marital status, number of children, socioeconomic background, ethnic origin, geographic location and the unemployment rate of the region), $\alpha_{i}$ is the individual-specific random component capturing the effect of time-invariant individual unobserved heterogeneity and $u_{i t}$ is an idiosyncratic error term distributed $N\left(0, \sigma_{u}^{2}\right) .^{3}$ Two problems arise if we estimate Equation (1) using a standard random effects framework.

The first problem arises from the assumption of zero correlation between the individual effect $\alpha_{i}$ and the explanatory variables $X_{i t}$ in the random effects model. We resolve this problem by implementing the Mundlak (1978) method which writes the relationship between $\alpha_{i}$ and the means of the time-varying $x$-variables as $\alpha_{i}=\bar{X}_{i}^{\prime} \delta+\varepsilon_{i}$, where $\varepsilon_{i} \sim i i d$ follows the normal distribution and is independent of $X_{i t}$ and $u_{i t}$ for all $i$ and $t$. Mundlak corrections can be applied by including on the right-hand side of Equation (1) the individual (over time) means for all time-varying explanatory variables.

The second problem arises from the possibility that the lagged dependent variable on the right-hand side of Equation (1) may be correlated with the error terms. This is known as the initial conditions problem. It has been examined by Heckman (1981), who proposed an estimator incorporating a linear approximation of the latent dependent variable at the initial

\footnotetext{
${ }^{3}$ Variables and their summary statistics are listed in Appendix Table A1.
} 
period, in order to express the joint probability of the observed sequence of individuals' experiences, given the individual effect $\alpha_{i}$. Simpler to compute estimators have been proposed by Orme (1997), Arulampalam and Stewart (2009), and Wooldridge (2005). ${ }^{4}$ We follow Wooldridge (2005) combined with Mundlak (1978) and estimate the following equation:

$y_{i t}^{*}=\gamma_{1} y_{i t-1}+\gamma_{2} L Q_{i t-1}+X_{i t}^{\prime} \beta+\bar{X}_{i}^{\prime} \delta+\theta y_{i 1}+\varepsilon_{i}+u_{i t}$

where $y_{i 1}$ represents the first observation of the binary dependent variable for individual $i$. All estimation results we present refer to Equation 2.

\section{Estimation Results}

We start by estimating the random effects dynamic probit model on the whole sample, followed by estimations on sub-samples, initially by gender and later by education level. The impact of low-paid employment and skills under-utilisation is estimated, separately. Knowing the crucial differences in the incidence and labour market outcomes of skills under-utilisation by education level, we also estimate the model with dynamics of skills under-utilisation by education level. The results highlight the role that education plays in determining the interrelated dynamics of unemployment and skills under-utilised employment.

We augment the presentation of the estimation by calculating several informative predicted probabilities and marginal effects. In Table 5 we present three additional predicted probabilities, the first one for present unemployment conditional on having been unemployed in the previous period, the second one for present unemployment conditional on having been employed below the low pay threshold in the previous period, and the third one for present

\footnotetext{
${ }^{4}$ Arulampalam and Stewart (2009) put Heckman's and the other estimators cited above to the test. They emphasise the benefits obtained from using the Mundlak correction and point out that all estimators provide similar results. Consequently, we chose the Wooldridge (2005) method for the purpose of this research.
} 
unemployment conditional on having been employed above the low pay threshold in the previous period. Similar predicted probabilities that condition on skills utilisation are presented in Table 6.

We also present in Tables 5 and 6 two types of marginal effects of unemployment and skills under-utilisation relative to skills well-utilised employment at $t-1$ on the probability of unemployment at $t$, following the counterfactual post-estimation approach used by Stewart (2007) and Buddelmeyer et al. (2010). The first type is the average partial effect (APE), which is defined as the difference between predicted probabilities; the second type is the predicated probability ratios (PPR), which is defined as the ratio between predicted probabilities. The latter is particularly useful in the present context because the reference for comparison, i.e. the predicted probability of unemployment at $t$ if in high paid or wellmatched employment at $t-1$, is often very small ( 0.022 and 0.023 , respectively for the whole sample). 
Table 5: The impact of previous unemployment and low paid employment on current unemployment probability

\begin{tabular}{|c|c|c|c|c|c|c|}
\hline & \multicolumn{2}{|l|}{ All } & \multicolumn{2}{|c|}{ Males } & \multicolumn{2}{|c|}{ Females } \\
\hline & Coef. & S.E. & Coef. & S.E. & Coef. & S.E. \\
\hline Unemployed at t-1 & $1.056^{* * *}$ & $(0.06)$ & $1.023^{* * *}$ & $(0.08)$ & $1.089^{* * *}$ & $(0.08)$ \\
\hline Low-paid at t-1 & $0.282 * * *$ & $(0.05)$ & $0.274 * * *$ & $(0.07)$ & $0.290 * * *$ & $(0.06)$ \\
\hline Initial unemployment & $0.916 * * *$ & $(0.06)$ & $0.968^{* * *}$ & $(0.09)$ & $0.849 * * *$ & $(0.09)$ \\
\hline Female & -0.019 & $(0.04)$ & & & & \\
\hline Only completed school & $-0.213^{* * *}$ & $(0.05)$ & $-0.369 * * *$ & $(0.08)$ & -0.073 & $(0.07)$ \\
\hline Certificates III/IV & $-0.158 * * *$ & $(0.05)$ & $-0.223 * * *$ & $(0.07)$ & -0.087 & $(0.07)$ \\
\hline Diplomas & $-0.141 * *$ & $(0.07)$ & -0.105 & $(0.10)$ & $-0.168 *$ & $(0.09)$ \\
\hline University graduates & $-0.310 * * *$ & $(0.05)$ & $-0.335 * * *$ & $(0.08)$ & $-0.271 * * *$ & $(0.07)$ \\
\hline Migrants (ESB) & $0.106^{*}$ & $(0.06)$ & $0.177^{* *}$ & $(0.09)$ & 0.006 & $(0.09)$ \\
\hline Migrants (NESB) & $0.227 * * *$ & $(0.06)$ & $0.246^{* * *}$ & $(0.09)$ & $0.195^{* *}$ & $(0.08)$ \\
\hline ATSI & $0.670 * * *$ & $(0.09)$ & $0.650 * * *$ & $(0.14)$ & $0.648^{* * *}$ & $(0.12)$ \\
\hline Father with a professional job & -0.032 & $(0.05)$ & -0.113 & $(0.08)$ & 0.056 & $(0.07)$ \\
\hline Married & -0.003 & $(0.07)$ & 0.065 & $(0.10)$ & -0.064 & $(0.10)$ \\
\hline Age & -0.033 & $(0.03)$ & -0.063 & $(0.04)$ & 0.003 & $(0.04)$ \\
\hline Age square & $0.061 *$ & $(0.04)$ & $0.097^{* *}$ & $(0.05)$ & 0.018 & $(0.05)$ \\
\hline Disability & $0.122 * *$ & $(0.06)$ & 0.103 & $(0.08)$ & $0.140^{*}$ & $(0.08)$ \\
\hline Urban & 0.152 & $(0.13)$ & $0.293 *$ & $(0.17)$ & -0.068 & $(0.21)$ \\
\hline Children aged under 5 & 0.111 & $(0.08)$ & 0.020 & $(0.11)$ & $0.222 *$ & $(0.13)$ \\
\hline Children aged [5, 14] & 0.113 & $(0.08)$ & 0.128 & $(0.11)$ & 0.095 & $(0.12)$ \\
\hline Regional unemployment rate & $0.109 * * *$ & $(0.02)$ & $0.116^{* * *}$ & $(0.03)$ & $0.098^{* *}$ & $(0.04)$ \\
\hline$m$ (married) & $-0.284 * * *$ & $(0.08)$ & $-0.486 * * *$ & $(0.12)$ & -0.123 & $(0.12)$ \\
\hline$m($ age $)$ & 0.007 & $(0.03)$ & 0.051 & $(0.04)$ & -0.041 & $(0.05)$ \\
\hline$m$ (age square) & -0.037 & $(0.04)$ & $-0.085^{*}$ & $(0.05)$ & 0.019 & $(0.06)$ \\
\hline$m$ (disability) & $0.305 * * *$ & $(0.09)$ & 0.176 & $(0.13)$ & $0.399 * * *$ & $(0.12)$ \\
\hline$m$ (urban) & -0.118 & $(0.14)$ & -0.284 & $(0.18)$ & 0.143 & $(0.23)$ \\
\hline m(children aged under 5) & -0.019 & $(0.11)$ & 0.130 & $(0.16)$ & -0.173 & $(0.17)$ \\
\hline$m$ (children aged $[5,14]$ ) & $-0.191 *$ & $(0.10)$ & $-0.277^{*}$ & $(0.15)$ & -0.091 & $(0.14)$ \\
\hline$m$ (regional unemployment rate) & -0.044 & $(0.03)$ & -0.071 & $(0.04)$ & 0.002 & $(0.06)$ \\
\hline Constant & $-1.983 * * *$ & $(0.25)$ & $-2.085^{* * *}$ & $(0.34)$ & $-1.988 * * *$ & $(0.39)$ \\
\hline No. of observations & 41,615 & & 21,693 & & 19,922 & \\
\hline Log-likelihood & -4490.29 & & -2390.71 & & -2078.19 & \\
\hline Prob(Ut|Ut-1) & 0.123 & & 0.117 & & 0.130 & \\
\hline Prob(Ut|LPt-1) & 0.037 & & 0.039 & & 0.035 & \\
\hline Prob(Ut|HPt-1) & 0.022 & & 0.024 & & 0.020 & \\
\hline APE & & & & & & \\
\hline Prob(Ut|Ut-1)-Prob(Ut|HPt-1) & 0.100 & & 0.093 & & 0.110 & \\
\hline Prob(Ut|LPt-1)-Prob(Ut|HPt-1) & 0.015 & & 0.015 & & 0.015 & \\
\hline PPR & & & & & & \\
\hline Prob(Ut|Ut-1)/Prob(Ut|HPt-1) & 5.500 & & 4.825 & & 6.455 & \\
\hline Prob(Ut|LPt-1)/Prob(Ut|HPt-1) & 1.667 & & 1.597 & & 1.755 & \\
\hline Prob(Ut|Ut-1)/Prob(Ut|LPt-1) & 3.299 & & 3.021 & & 3.678 & \\
\hline
\end{tabular}

Note: Dependent variable is the probability of unemployment at t. m(.) denotes Mundlak correction terms. $* * * \mathrm{p}<0.01, * * \mathrm{p}<0.05, * \mathrm{p}<0.1$ 
Results obtained from the whole sample and for men and women separately are reported in Tables 5 and 6. The statistical significance of initial unemployment and some of the Mundlak correction terms in Table 5 suggest that the combination of the Wooldridge method with the Mundlak corrections is an appropriate method for the control of initial conditions and individual unobserved heterogeneity. The Mundlak corrections are more significant for the complete sample, indicating that unobserved individual heterogeneity is reduced when we split the sample by gender.

Results in Tables 5 are in line with the results from the existing literature, suggesting that unemployment is persistent. In other words, for those who were unemployed rather than working at $t-1$, unemployment status leads to a higher likelihood of being unemployed in year $t$, not only because of the individual observed and unobserved individual characteristics, but also because they were unemployed at $t-1$. Some estimated differences are noteworthy. For example, comparing those who were paid above the threshold pay in the previous period with those who were unemployed in the previous period, we find that the probability of unemployment is higher by 0.100 (or 5.5 times as likely as the PPR estimate shows) for those who were unemployed in $t-1$. The difference in unemployment probability between those who were below and above the low pay threshold is shown in Table 5 to be 0.015 (or 1.67 times as likely as the PPR estimate shows).

Table 6 contains findings that are new in the literature and show statistically significant effects of past skills under-utilisation on present outcomes. The probability of present unemployment is higher for those who were employed in a skills-underutilised job in the previous period. Compared to those who were employed in a skills well-matched job in the previous period, the probability of present unemployment is higher by 0.077 (or 4.4 times as 
likely as the PPR estimate shows) than for those who were unemployed in the previous period. While those who were employed in the previous period were not very likely to be unemployed in the next period, those who were skills under-utilised were 1.39 times more likely to become unemployed than those who were skills well-matched. Estimations by gender suggest that the results are very similar for males and females, a finding that is in line with most findings on mismatch, where gender differences are typically small.

Our findings indicate that there exists a dynamic relationship not only between past and present unemployment, but also between past skills under-utilisation and present unemployment, though the latter effect appears to be relatively weaker. The conventional explanation for the dynamic effect of unemployment is that when a person is unemployed, some of their skills may be lost or the fact of being unemployed may signal such a loss to potential employers. The outcome is that the probability of re-employment becomes lower for these reasons. In an analogous way one can think of a skills under-utilised employee, as an employee who is under-employed, and in an analogous way may be perceived as more likely to have lost some valuable skills. This perception may not matter if the worker concerned remains employed and in the same job. However, should these workers need to get another job (either because of a quit or a layoff), they may find it harder to find a new job because of the signal their previous under-utilised job conveys to perspective employers. This effect is revealed by the estimation of the difference in the probability of being unemployed between those who are under-utilised and those who are well-matched. Our results show that the (small) probability of being unemployed is close to 40 per cent higher for those who were previously under-utilised than those who were well-matched. 
Table 6: The impacts of previous unemployment and skill under-utilisation on current unemployment probability

\begin{tabular}{|c|c|c|c|c|c|c|}
\hline & \multicolumn{2}{|c|}{ All sample } & \multicolumn{2}{|c|}{ Males } & \multicolumn{2}{|c|}{ Females } \\
\hline & Coef. & S.E. & Coef. & S.E. & Coef. & S.E. \\
\hline Unemployed at $\mathrm{t}-1$ & $0.984^{* * *}$ & $(0.06)$ & $1.016^{* * *}$ & $(0.09)$ & $0.960 * * *$ & $(0.09)$ \\
\hline Under-utilised at $\mathrm{t}-1$ & $0.201^{* * *}$ & $(0.04)$ & $0.227 * * *$ & $(0.06)$ & $0.179 * * *$ & $(0.06)$ \\
\hline Initial unemployment & $1.332 * * *$ & $(0.08)$ & $1.422 * * *$ & $(0.12)$ & $1.213^{* * *}$ & $(0.10)$ \\
\hline Female & -0.028 & $(0.04)$ & & & & \\
\hline Only completed school & $-0.245^{* * *}$ & $(0.06)$ & $-0.465 * * *$ & $(0.10)$ & -0.070 & $(0.08)$ \\
\hline Certificates III/IV & $-0.135 * *$ & $(0.06)$ & $-0.182 * *$ & $(0.08)$ & -0.077 & $(0.08)$ \\
\hline Diplomas & $-0.196 * *$ & $(0.08)$ & $-0.201 *$ & $(0.12)$ & $-0.174 *$ & $(0.10)$ \\
\hline University graduates & $-0.338 * * *$ & $(0.06)$ & $-0.317 * * *$ & $(0.09)$ & $-0.330 * * *$ & $(0.08)$ \\
\hline Migrants (ESB) & $0.140^{* *}$ & $(0.07)$ & $0.192 *$ & $(0.10)$ & 0.060 & $(0.10)$ \\
\hline Migrants (NESB) & $0.257 * * *$ & $(0.07)$ & $0.240^{* *}$ & $(0.10)$ & $0.249 * * *$ & $(0.09)$ \\
\hline ATSI & $0.709 * * *$ & $(0.11)$ & $0.825^{* * *}$ & $(0.17)$ & $0.585^{* * *}$ & $(0.14)$ \\
\hline Father with a professional job & -0.031 & $(0.06)$ & -0.022 & $(0.09)$ & -0.033 & $(0.08)$ \\
\hline Married & 0.013 & $(0.08)$ & 0.073 & $(0.12)$ & -0.000 & $(0.12)$ \\
\hline Age & $-0.058^{*}$ & $(0.03)$ & -0.060 & $(0.04)$ & -0.058 & $(0.05)$ \\
\hline Age square & $0.086^{* *}$ & $(0.04)$ & 0.086 & $(0.05)$ & 0.092 & $(0.06)$ \\
\hline Disability & $0.158^{* *}$ & $(0.07)$ & $0.173^{*}$ & $(0.10)$ & 0.139 & $(0.09)$ \\
\hline Urban & 0.130 & $(0.16)$ & $0.348^{*}$ & $(0.21)$ & -0.178 & $(0.23)$ \\
\hline Children aged under 5 & 0.120 & $(0.09)$ & -0.055 & $(0.13)$ & $0.326^{* *}$ & $(0.14)$ \\
\hline Children aged [5, 14] & 0.079 & $(0.09)$ & -0.022 & $(0.13)$ & 0.189 & $(0.13)$ \\
\hline Regional unemployment rate & $0.092 * * *$ & $(0.02)$ & $0.094 * * *$ & $(0.03)$ & $0.089 * *$ & $(0.04)$ \\
\hline$m$ (married) & $-0.378 * * *$ & $(0.10)$ & $-0.573 * * *$ & $(0.15)$ & $-0.268 * *$ & $(0.13)$ \\
\hline$m$ (age) & 0.016 & $(0.03)$ & 0.028 & $(0.05)$ & 0.007 & $(0.05)$ \\
\hline$m$ (age square) & -0.040 & $(0.04)$ & -0.048 & $(0.06)$ & -0.037 & $(0.06)$ \\
\hline$m$ (disability) & $0.283 * * *$ & $(0.10)$ & 0.171 & $(0.15)$ & $0.358 * * *$ & $(0.13)$ \\
\hline$m$ (urban) & -0.085 & $(0.17)$ & $-0.407^{*}$ & $(0.23)$ & 0.347 & $(0.25)$ \\
\hline m(children aged under 5) & 0.072 & $(0.13)$ & 0.246 & $(0.18)$ & -0.130 & $(0.19)$ \\
\hline$m$ (children aged $[5,14]$ ) & -0.106 & $(0.11)$ & -0.025 & $(0.17)$ & -0.175 & $(0.15)$ \\
\hline$m$ (regional unemployment rate) & 0.002 & $(0.04)$ & -0.009 & $(0.05)$ & 0.014 & $(0.06)$ \\
\hline Constant & $-1.989 * * *$ & $(0.27)$ & $-2.084 * * *$ & $(0.37)$ & $-1.948 * * *$ & $(0.41)$ \\
\hline No. of observations & 39,127 & & 19,924 & & 19,203 & \\
\hline Log-likelihood & -3862.27 & & -1960.43 & & -1880.51 & \\
\hline Prob(Ut|Ut-1) & 0.100 & & 0.101 & & 0.101 & \\
\hline Prob(Ut|OSt-1) & 0.032 & & 0.034 & & 0.030 & \\
\hline Prob(Ut|WMt-1) & 0.023 & & 0.024 & & 0.021 & \\
\hline \multicolumn{7}{|l|}{ APE } \\
\hline Prob(Ut|Ut-1)-Prob(Ut|WMt-1) & 0.077 & & 0.077 & & 0.080 & \\
\hline Prob(Ut|OSt-1)-Prob(Ut|WMt-1) & 0.009 & & 0.010 & & 0.008 & \\
\hline \multicolumn{7}{|l|}{ PPR } \\
\hline Prob(Ut|Ut-1)/Prob(Ut|WMt-1) & 4.391 & & 4.237 & & 4.723 & \\
\hline Prob(Ut|OSt-1)/Prob(Ut|WMt-1) & 1.394 & & 1.422 & & 1.378 & \\
\hline Prob(Ut|Ut-1)/Prob(Ut|OSt-1) & 3.150 & & 2.979 & & 3.426 & \\
\hline
\end{tabular}

Note: Dependent variable is the probability of unemployment at t. $\mathrm{m}($.) denotes Mundlak correction terms. *** $\mathrm{p}<0.01,{ }^{* *} \mathrm{p}<0.05,{ }^{*} \mathrm{p}<0.1$ 
Results from the remaining control variables suggest that disadvantaged groups, such as the very young or the very old, people with a disability or a long-term health condition, migrants, and aboriginal and Torres Strait Islanders, are all associated with higher unemployment probabilities. Also, the probability of unemployment in general decreases with the level of education with the sole exception of VET graduates (Diplomas and Certificates III/IV) who are more likely to be unemployed than school completers. The high statistical significance of all education level variables and their differences by gender points to the next estimation step which extends the results in Table 6 by education level. We present the results in Table 7 below. ${ }^{5}$

Table 7 shows that there is a significant and negative effect of past skills under-utilisation and an even much stronger negative effect of unemployment experience (relative to skills wellutilised employment) on current employment, for all education levels. Results show two main patterns. First, the more academic education qualifications (that is, university degrees and completed school education) are more protective against unemployment than the vocational qualifications or no qualifications at all. All three predicted probabilities are lower for university and school graduates. The differences are large. For example an unemployed university degree holder has a 4.9 per cent probability of remaining unemployed, against a 14.1 per cent probability of a VET (Certificate III/IV) holder. Second, for all education levels, a well-matched job is protective of future unemployment. For instance, a wellmatched university graduate is about half as likely to become unemployed as a mismatched counterpart (0.011/0.022), while a well-matched school non-completer is about 80 per cent as likely to become unemployed as a mismatched counterpart (0.041/0.052). University

\footnotetext{
${ }^{5}$ One important finding is that for those with diplomas the estimated cross-period correlation between composite error terms $\rho$ is close to zero, indicating that a low proportion of the error variance is due to an individual unobserved effect $\varepsilon_{i}$. Under these circumstances, RE estimates will be similar to the pooled estimates and panel estimation methods may be problematic. Therefore, we will not discuss the results for diplomas in more detail here.
} 
graduates not only are less likely to remain unemployed, but they also are less likely to become unemployed if they have been in a skills well-utilised job. The converse argument also holds in that these results show that the penalty of mismatch (in the form of increasing unemployment probability relative to a well matched person with the same qualifications) is at its highest for university graduates (1.959 times as likely) and at its lowest for school noncompleters (1.26 times as likely). The two results simply represent the two sides of the same coin. However, these comparisons have to be seen in the context of the very different absolute values for each education level. For example, although university graduates have the lowest unemployment probabilities, it is still the case that a university graduate who was previously unemployed is more likely to be unemployed at present than any of the lower qualifications workers who were previously in a well-matched job (this compares a 4.9 per cent probability for the university graduate with a 2 per cent, 2.9 per cent and 4.1 per cent probability for each of the other three education levels)

Having higher educational attainment seems to enhance the probability of employment, but this is true only for those who were employed in the previous period. Among those in wellmatched employment at $t-1$, the probability of unemployment at $t$ is reduced from 0.041 for school non-completers to 0.011 for university graduates. Similarly, for those in under-utilised employment at $t-1$, the likelihood of unemployment at $t$ is reduced from 0.052 to 0.022 . In contrast, having better qualifications does not necessarily have a positive impact on employment probabilities for those who were previously unemployed. Getting a job is relatively easier for those who hold a university degree or have only completed school rather than holding a certificate III/IV or having not completed school. This finding indicates that the incentive to invest in human capital will be reduced when skills are not effectively utilised. 
With regard to the magnitude of the adverse effect of unemployment experience (relative to skills well-utilised employment) on repeat unemployment, VET graduates have the largest effect in terms of the differences (APE is 0.121 for certificates III/IV). By contrast, the weakest effect is found for university graduates and school completers, with APE values at 0.038 and 0.041 , respectively. However, the ratio measure of the effect of PPR on graduates is 4.303, which is higher than those with no post-school qualification (at 3.467) due to a very small probability of unemployment for degree holders who were in a skills well-matched job in the previous period.

Finally, Table 7 shows that skills under-utilised employment (relative to well-utilised employment) at $t-1$ significantly enhances the probability of unemployment at $t$ for all educational categories. The scales of those effects are similar in terms of APE (around 0.01), which are small in size but statistically significant. In contrast, PPR strictly increases with education ranging from 1.260 for school non-completers to 1.959 for university graduates. The implication of this result is that getting unemployed people into work is a considerable step towards more stable employment as it increases the probability of future employment. However, only getting a job may not be as beneficial as getting a well matched job, especially for those who have relatively high qualifications. Those who get into a skills under-utilised job, are still much more likely to be unemployed in the next period, compared to those who get a well-matched job. For university graduates the figure is about twice as high (1.959). For VET graduates, it is about one and half times as high (1.485). 
Table 7: Random effects dynamic model for unemployment probability by education level

\begin{tabular}{|c|c|c|c|c|c|c|c|c|}
\hline & \multicolumn{2}{|c|}{$\begin{array}{l}\text { University } \\
\text { graduates }\end{array}$} & \multicolumn{2}{|c|}{ Certificates III/IV } & \multicolumn{2}{|c|}{$\begin{array}{l}\text { Only completed } \\
\text { school }\end{array}$} & \multicolumn{2}{|c|}{$\begin{array}{l}\text { Did not complete } \\
\text { school }\end{array}$} \\
\hline & Coef. & S.E. & Coef. & S.E. & Coef. & S.E. & Coef. & S.E. \\
\hline Unemployed at t-1 & $0.790 * * *$ & $(0.16)$ & $1.183 * * *$ & $(0.12)$ & $0.651^{* * *}$ & $(0.16)$ & $1.066^{* * *}$ & $(0.11)$ \\
\hline Under-utilised at t-1 & $0.344 * * *$ & $(0.09)$ & $0.210 * *$ & $(0.09)$ & $0.238 * *$ & $(0.11)$ & $0.180 * *$ & $(0.09)$ \\
\hline Initial unemployment & $1.291^{* * *}$ & $(0.18)$ & $1.058^{* * *}$ & $(0.14)$ & $1.830 * * *$ & $(0.24)$ & $1.499 * * *$ & $(0.17)$ \\
\hline Female & -0.107 & $(0.09)$ & -0.027 & $(0.08)$ & $0.313^{* * *}$ & $(0.11)$ & -0.098 & $(0.09)$ \\
\hline Migrants (ESB) & 0.097 & $(0.14)$ & $0.233^{*}$ & $(0.13)$ & 0.217 & $(0.19)$ & -0.048 & $(0.16)$ \\
\hline Migrants (NESB) & $0.386^{* * *}$ & $(0.11)$ & $0.372 * * *$ & $(0.13)$ & 0.192 & $(0.18)$ & -0.095 & $(0.21)$ \\
\hline ATSI & $0.648 * *$ & $(0.31)$ & $0.856 * * *$ & $(0.19)$ & 0.068 & $(0.31)$ & $0.914^{* * *}$ & $(0.20)$ \\
\hline Father with a professional job & 0.008 & $(0.09)$ & -0.168 & $(0.14)$ & 0.046 & $(0.14)$ & 0.113 & $(0.17)$ \\
\hline Married & -0.127 & $(0.19)$ & -0.097 & $(0.17)$ & -0.043 & $(0.20)$ & 0.231 & $(0.17)$ \\
\hline Age & -0.000 & $(0.08)$ & $-0.127^{*}$ & $(0.07)$ & -0.051 & $(0.08)$ & -0.089 & $(0.07)$ \\
\hline Age square & 0.027 & $(0.09)$ & $0.156^{*}$ & $(0.09)$ & 0.098 & $(0.11)$ & 0.119 & $(0.08)$ \\
\hline Disability & 0.151 & $(0.15)$ & $0.231^{*}$ & $(0.12)$ & 0.001 & $(0.19)$ & 0.097 & $(0.13)$ \\
\hline Urban & 0.719 & $(0.44)$ & 0.378 & $(0.31)$ & 0.103 & $(0.45)$ & -0.125 & $(0.29)$ \\
\hline Children aged under 5 & 0.154 & $(0.20)$ & 0.144 & $(0.18)$ & 0.081 & $(0.25)$ & 0.000 & $(0.19)$ \\
\hline Children aged $[5,14]$ & -0.243 & $(0.19)$ & 0.235 & $(0.17)$ & 0.164 & $(0.27)$ & $0.340^{*}$ & $(0.20)$ \\
\hline Regional unemployment rate & 0.079 & $(0.05)$ & $0.097 * *$ & $(0.05)$ & $0.159 * *$ & $(0.07)$ & 0.054 & $(0.05)$ \\
\hline Constant & $-2.914^{* * *}$ & $(0.80)$ & $-2.366 * * *$ & $(0.56)$ & $-1.783^{* * *}$ & $(0.65)$ & $-2.545^{* * *}$ & $(0.50)$ \\
\hline No. of observations & 11,737 & & 8728 & & 5,885 & & 8,918 & \\
\hline Log-likelihood & -745.95 & & -874.04 & & -624.97 & & -1223.51 & \\
\hline Prob(Ut|Ut-1) & 0.049 & & 0.141 & & 0.069 & & 0.143 & \\
\hline $\operatorname{Prob}(\mathrm{Ut} \mid \mathrm{OSt}-1)$ & 0.022 & & 0.030 & & 0.040 & & 0.052 & \\
\hline Prob(Ut|WMt-1) & 0.011 & & 0.020 & & 0.029 & & 0.041 & \\
\hline \multicolumn{9}{|l|}{ APE } \\
\hline Prob(Ut|Ut-1)-Prob(Ut|WMt-1) & 0.038 & & 0.121 & & 0.041 & & 0.102 & \\
\hline Prob(Ut|OSt-1)-Prob(Ut|WMt-1) & 0.011 & & 0.010 & & 0.011 & & 0.011 & \\
\hline \multicolumn{9}{|l|}{$P P R$} \\
\hline Prob(Ut|Ut-1)/Prob(Ut|WMt-1) & 4.303 & & 6.910 & & 2.423 & & 3.467 & \\
\hline Prob(Ut|OSt-1)/Prob(Ut|WMt-1) & 1.959 & & 1.485 & & 1.399 & & 1.260 & \\
\hline Prob(Ut|Ut-1)/Prob(Ut|OSt-1) & 2.196 & & 4.653 & & 1.732 & & 2.751 & \\
\hline
\end{tabular}

Note: Dependent variable is the probability of unemployment at t. Mundlak correction terms are included in the regression but not presented here.

*** $\mathrm{p}<0.01,{ }^{* *} \mathrm{p}<0.05,{ }^{*} \mathrm{p}<0.1$ 


\section{Conclusion}

This paper uses the first ten waves of the HILDA survey data to investigate the inter-related dynamics of unemployment and skills utilisation in the workplace in Australia. In particular, we examine the influence of the scarring effects of experiencing low pay, skills underutilisation, and unemployment on the probability of future unemployment. We estimate the random effects dynamic probit model developed by Wooldridge (2005) with Mundlak (1978) corrections, in order to control for both initial conditions and individual unobserved heterogeneity.

We find that both male and female low paid workers are significantly more likely to be unemployed in the next period relative to high paid workers. Similarly, skills under-utilised workers are significantly more likely to be unemployed in the next period relative to skills well-matched workers. A universal result in our analysis is that the likelihood of unemployment in the next period is higher for those who are unemployed in the current period. Combining these results suggests that there are scarring effects, not only of unemployment, but also of low pay and skills under-utilisation on future employment probabilities, though we find, not unexpectedly, that the skills under-utilisation effects and the low pay effects are relatively weaker than the unemployment effects.

The adverse effect of low pay, skills under-utilisation and unemployment experience on future employment prospects is significant for both males and females and we do not find any discernible gender differences. We find significant effects for all education levels, with substantial differences between education levels. Being presently well matched is protective against future unemployment for all education levels, and when mismatched and wellmatched workers are compared within each education level, being well matched is most protective against future unemployment for university graduates. 
From the point of view of policy, getting individuals out of unemployment is an important policy goal, but in the long-term getting them into jobs which are relatively well paid and in which their skills are well utilised will have a much bigger potential pay-off. 


\section{References}

Allen, J. and Van der Velden, R., 2001. Educational Mismatch Versus Skill Mismatches: Effects on Wage, Job Satisfaction and On-the-Job Search. Oxford Economic Papers, 53, 43452.

Arulampalam,W., Booth, A. and Taylor M., 2000. Unemployment Persistence. Oxford Economic Papers, 52, 24-50.

Baert S.,Cockx B. and Verhaest D., 2013, Over-education at the Start of the Career: Stepping Stone or Trap?, Labour Economics, dx.doi.org/10.1016/j.labeco/2013.04.013.

Buddelmeyer, H., Lee, W. and Wooden, M., 2009. Low-paid Employment and Unemployment Dynamics in Australia. Economic Record, 86, 28-48.

CEDEFOP, 2010. The Skill Matching Challenge: Analysing Skill Mismatch and Policy Implications, Luxembourg.

CEDEFOP, 2012. Dynamics of Skill Mismatch and Labour Market Transitions, Luxembourg.

Clark K. and Kanellopoulos N., 2013, Low Pay Persistence in Europe, Labour Economics, (forthcoming).

Desjardins, R. and Rubenson, K., 2011. An Analysis of Skill Mismatch Using Direct Measures of Skills. OECD Education Working Papers, No. 63, OECD Publishing.

European Commission, 2009. New Skills for New Jobs: Anticipating and Matching Labour Market and Skill Needs, Luxembourg.

European Commission, 2012. Employment and Social Developments in Europe 2012, Luxembourg.

Flaig, G., Licht, G. and Steiner, V., 1993. Testing for State Dependence Effects in a Dynamic Model of Male Unemployment Behaviour. In H. Bunzel et al. (eds.) Panel Data and Labour Market Dynamics, Amsterdam: North-Holland.

Frijters, P., Lindeboom, M. and van den Berg, G., 2000. Persistencies in the Labour market. Working Paper, Free University Amsterdam.

Gosling, A., Johnson, P., McCrae, J. and Paul, G., 1997. The Dynamics of Low Pay and Unemployment in Early 1990s Britain. Institute of Fiscal Studies, London.

Green F. and Zhu Y., 2010. Overqualification, Job Dissatisfaction, and Increasing Dispersion in the Returns to Graduate Education. Oxford Economic Papers, 62, 740-763.

Heckman, J. 1981. Heterogeneity and State Dependence. In S. Rosen (ed.) Studies in Labor Markets, Chicago: University of Chicago Press (for NBER).

Hyslop, D. 1999. State Dependence, Serial Correlation and Heterogeneity in Intertemporal Labor Force Participation of Married Women. Econometrica, 67, 1255—94. 
Mavromaras, K., McGuinness, S and Fok, K., 2009. Assessing the Incidence and Wage Effects of Overskilling in the Australian Labour Market. Economic Record, 85, 60-72.

Mavromaras, K., McGuinness, S., O’Leary, N., Sloane, P. and Fok, K., 2010. The Problem of Overskilling in Australia and Britain. Manchester School, 78, 219-41.

Mavromaras, K., Mahuteau, S., Sloane, P. and Wei, Z., 2012. The Persistence of Overskilling and its Effects on Wages. National Vocational Education and Training Research and Evaluation Program Report, NCVER, Australia.

Mavromaras, K. and McGuinness, S., 2012 b. Overskilling Dynamics and Education Pathways. Economics of Education Review, 31, 619-28.

McGuinness, S. and Wooden, M., 2009. Overskilling, Job Insecurity and Career Mobility. Industrial Relations, 48, 265-86.

Muhleisen, M. and Zimmermann, K., 1994. A Panel Analysis of Job Changes and Unemployment, European Economic Review, 38, 793-801.

Mundlak, Y., 1978. On the Pooling of Time Series and Cross Section Data. Econometrica, 46, 69-85.

Narendranathan, W. and Elias, P., 1993. Influences of Past History on the Incidence of Youth Unemployment: Empirical Findings for the UK. Oxford Bulletin of Economics and Statistics, $55,161-85$.

Sattinger, M., 2012. Qualitative Mismatches. Foundations and Trends in Microeconomics, 8, 1-168.

Sloane, P. and Theodossiou, I., 1996. Earnings Mobility, Family Income and Low Pay. The Economic Journal, 106, 657-66.

Sloane, P. and Theodossiou, I., 1998. An Econometric Analysis of Low Pay and Earnings Mobility in Britain. in R. Asplund, P. Sloane and I. Theodossiou (eds), Low Pay and Earnings Mobility in Europe. Edward Elgar, Cheltenham.

Stewart, M., 2007. The Inter-related Dynamics of Unemployment and Low Pay. Journal of Applied Econometrics, 22, 511-31.

Stewart, M. and Swaffield, J., 1997. The Dynamics of Low Pay in Britain. In P. Gregg (ed.), Jobs, Wages and Poverty: Patterns of Persistence and Mobility in the Flexible Labour Market. Centre for Economic Performance, London.

Watson, N. and Wooden, M., 2004. The HILDA Survey Four Years On. Australian Economic Review, 37, 343-349. 
Wooldridge, J., 2005. Simple Solutions to the Initial Conditions Problem in Dynamic, Nonlinear Panel Data Models with Unobserved Heterogeneity. Journal of Applied Econometrics, 20, 39-54. 


\section{Appendix}

Table A1: Descriptive statistics

\begin{tabular}{lrr}
\hline & Mean & Standard deviation \\
\hline Female & 0.488 & 0.500 \\
Only completed school & 0.167 & 0.373 \\
Certificates III/IV & 0.220 & 0.414 \\
Diplomas & 0.092 & 0.289 \\
University graduates & 0.270 & 0.444 \\
Migrants (ESB) & 0.093 & 0.290 \\
Migrants (NESB) & 0.103 & 0.304 \\
ATSI & 0.022 & 0.146 \\
Father with a profession job & 0.156 & 0.363 \\
Married & 0.658 & 0.474 \\
Age & 37.753 & 11.841 \\
Age square/100 & 15.655 & 9.130 \\
Disability & 0.132 & 0.339 \\
Urban & 0.877 & 0.329 \\
Children aged under 5 & 0.125 & 0.330 \\
Children aged [5, 14] & 0.252 & 0.434 \\
Regional unemployment rate & 5.442 & 1.139 \\
\hline
\end{tabular}

Note: Pooled data from HILDA 2001-2010. Number of observations is 64405. 